Кириленко С. В.

\begin{abstract}
Аннотация. Цель исследования - выполнить обзор современных социолингвистических исследований с целью выявления новых терминологических единиц. Научная новизна работы заключается в описании малоизвестных терминов, которые появились в области исследования диалектов, билингвизма, мультилингвизма и языковых изменений. В результате исследования был выявлен ряд недавно появившихся социолингвистических терминов (бидиалектизм и его типы, возрастная градация говорящих, комплементация изоглосс, градиент, дискурсивный коллектив, социетальный билингвизм и др.), которые, вероятно, со временем займут свое место в понятийном аппарате и терминосистеме социальной лингвистики.
\end{abstract}

\section{EN Expansion of Sociolinguistic Research Terminology in the Field of Dialectology, Language Changes, Multilingualism}

\section{Kirilenko S. V.}

\begin{abstract}
The aim of the study is to review modern sociolinguistic research in order to identify new terminological units. The scientific originality of the work lies in the description of little-known terms that have appeared in the field of the study of dialects, bilingualism, multilingualism and linguistic changes. As a result of the study, a number of recently appeared sociolinguistic terms (bidialectism and its types, age gradation of speakers, isogloss complementation, gradient, discursive collective, societal bilingualism, etc.) were identified, which will probably take their place in the conceptual apparatus and terminology of social linguistics in length of time.
\end{abstract}

\section{Введение}

Термин «социолингвистика», как во всем мире признается учеными, был впервые предложен Хавером С. Карри в 1952 году в его работе «Проекция социолингвистики: взаимосвязь речи и социального статуса» (Currie, 1952). В этой работе автор описывал направления в лингвистике и диалектологии, которые потенциально могли образовать новую область исследований. С середины 1960-х годов начали проводиться первые социолингвистические конференции. Появилось множество исследовательских работ и книг о взаимосвязи структуры языка и языкового поведения говорящих. С тех пор прошло уже более шестидесяти лет, и в социальной лингвистике появилось множество теорий и методологий. Направления современных социолингвистических исследований ученых зачастую не совпадают по методологии, но при этом взаимно дополняют, расширяют и укрепляют исследовательскую базу.

Существует общее направление социолингвистической проблематики, разрабатываемое учеными во всем мире. Оно в основном связанно с развитием терминосистемы социальной лингвистики, расширением взаимосвязей понятийного аппарата, уточнением основных методологических понятий. Наряду с этим бурно развивается множество отдельных направлений социолингвистических исследований. Актуальность темы исследования обусловлена тем, что на основе терминологии формируется коммуникация ученых в любой науке, поэтому важно расширять научный понятийный аппарат для таких недавно зародившихся научных направлений, как социолингвистика.

Задачи исследования заключались в анализе последних тенденций развития социолингвистической мысли с точки зрения выявления новых терминологических единиц. В связи с этим в работе применялись описательные и сопоставительные методы исследования: представлен обзор значимых работ авторов по нескольким социолингвистическим направлениям: социальным диалектам, речевым коллективам, билингвизму и мультилингвизму. 
Теоретической базой исследования послужил ряд трудов зарубежных социолингвистов Р. Баррета (Barrett, 2006), Дж. Дочерти (Docherty, 2005), В. Йоссе (Yousse, 2009), Х. Карри (Currie, 1952), У. Лабова (Labov, 2007; Labov, Ash, Boberg, 2006), Дж. Освальда (Oschwald, Schättin, Bastian, Souza, 2018), А. Портеса (Portes, 1998), П. Традгилла (Trudgill, 2003), К. Хазена (Hazen, 2001), посвященных мультилингвизму, языковым изменениям, диалектам и социолектам.

Практическая значимость. Полученные данные по терминологическим единицам можно использовать в процессе преподавания таких дисциплин, как социолингвистика, лингвосоциология, социология. Также эти новые термины, несомненно, войдут с состав нового издания «Словаря социолингвистических терминов» (2006) (Словарь социолингвистических терминов, 2006).

\section{Основная часть}

Диалектология в социолингвистике в основном сфокусирована на изучении диалектного членения языков с точки зрения разделения их на территориальные языковые образования, при этом традиционно анализируется уровень дивергенции идиомов, входящих в состав изучаемого языка. Заметным исследованием региональных диалектов является работа У. Лабова, Ш. Эша и Ч. Боберга «Атлас североамериканского английского языка» (Labov, Ash, Boberg, 2006), где представлены данные по фонологическим отличиям региональных диалектов английского языка. В атласе проанализированы фонетические особенности произношения в городских районах США и Канады, исследование проводилось в конце 1990-х - начале 2000-х годов. Изучались связи между географическим распространением диалектов и их лингвистическими особенностями. В атласе отражено влияние внутренних социальных факторов на появление диалектных особенностей, описаны причины региональной дифференциации диалектов, выдвинуты предположения о взаимосвязях линий коммуникации говорящих и диалектных границ (речь идет об известных изоглоссах: Северная/Срединная и Срединная/Южная). Авторы атласа приходят к выводу, что звуковые изменения диалектов американского английского языка продолжаются, причем темпы изменений все больше ускоряются, что является новой социолингвистической характеристикой, причем объяснение причин появления этой тенденции выявлено не было. Параллельно с этим расширяется разнообразие американских диалектов, и это явление носит не локальный, а региональный характер. В части терминологии известным термином является переплетение изоглосс. Малоизвестными терминами здесь являются комплементация изоглосс (complementation) и гнездование изоглосс (nesting). Комплементация изоглосс - обозначает места, где изоглоссы не пересекаются, образуя таким образом взаимоисключающие диалектные области: “...the complementation of isoglosses is the degree to which they do not overlap, defining mutually exclusive dialect areas” («...комплементация изоглосс - это степень до которой они не пересекаются, образуя взаимоисключающие диалектные области») (Labov, Ash, Boberg, 2006, с. 42). Гнездование изоглосс имеет место, в случае если пространственное распределение одной диалектной особенности полностью содержится внутри другой, устанавливая имплицитную взаимосвязь: “...isoglosses are nested when the spatial distribution of one feature is contained entirely within that of an other, establishing an implicational relationship” («...гнездование изоглосс происходит в случае, когда пространственное распространение одной диалектной особенности сдерживается в пределах другой диалектной особенности, образуя импликационную взаимосвязь») (Labov, Ash, Boberg, 2006, с. 42-43). Актуальным и новым направлением в социолингвистической диалектологии стала социофонетика, которая изучает фонетику в социолингвистическом аспекте. Исследователи Дж. Дочерти и П. Фоукс проанализировали акустические характеристики фонетических звуков речи с целью изучения особенностей региональной вариации, социальных изменений, стилистических изменений или языковых изменений. Они утверждают, что существует социо-фонетическое разграничение в использовании определенных согласных звуков, на которое оказывает влияние социальная идентичность говорящих (Docherty, 2005). В социофонетике диалектов исследуются смешанные диалекты (mixed dialects) и уклоняющиеся диалекmы (fudged dialects). В смешанных диалектных особенностях произношения имеют место заимствования у соседних диалектов, а в уклоняющихся диалектах говорящие используют новый вариант произношения, не похожий на существующие, а являющийся фонетически промежуточным (A Dictionary of Sociolinguistics, 2012, с. 29-30).

Новым направлением исследований стал бидиалектизм. Этот термин обозначает использование двух диалектов в речи говорящего. Изучается влияние бидиалектизма на языковые способности говорящих (Oschwald, Schättin, Bastian, 2018). Различаются рецееттивный и продуктивный бидиалектизм (Hazen, 2001). Рецептивный бидиалектизм обозначает способность говорящего понимать высказывания на диалектах своего языка, а продуктивный бидиалектизм обозначает способность продуцировать речь на двух диалектах.

Речевые коллективы - это группы людей, объединенные такими потребностями в коммуникации, как социализация и групповая солидарность, эти коллективы основаны на общих интересах (Словарь социолингвистических терминов, 2006, с. 186). Они характеризуются употреблением в речи определенного ограниченного набора языковых единиц, их речевой репертуар основан на соблюдении общих правил выбора и употребления языковых средств, необходимости следования социокультурным речевым нормам, общим для этого речевого коллектива, и соблюдения общности в интерпретациях высказываний. При изучении речевых коллективов в синонимичном значении используется также термин дискурсивный коллектив (discourse community) (Trudgill, 2003, c. 46).

В социолингвистике активно исследуются диахронические языковые изменения в речевых коллективах. В данной области анализируется роль возраста говорящего как социального фактора, начало изучению этого вопроса было заложено У. Лабовым, У. Вайнрайх в 1960-х годах. Со временем появился термин “age grading”, 
возрастная градация говорящих, обозначающий явление, при котором говорящие в речевом сообществе постепенно изменяют свои речевые привычки по мере взросления, причем этот тип изменений повторяется в каждом новом поколении. Определённые лингвистические формы чаще используются молодежью (сленг), и в дальнейшем по мере взросления от этих речевых практик отказываются. Было доказано, что в некоторых речевых сообществах говорящие, по мере взросления, начинают использовать в речи черты, свойственные акролекту, а затем, по достижении пенсионного возраста, снова возвращаются к менее престижным речевым паттернам. Под акролектом здесь понимается вариант языка, наиболее подходящий для общения в формальной ситуации. Возрастная градация говорящих - это то явление, которое нужно обязательно учитывать при изучении лингвистических изменений во времени, чтобы убедиться, что из языковых различий между поколениями не делаются ложные выводы.

В своей работе «Трансмиссия и диффузия» (2007) У. Лабов сравнивает передачу языковых изменений, трансмиссию, внутри отдельного речевого коллектива с диффузией, причем при трансмиссии характеристики языкового варианта сохраняются, а с диффузией они утрачиваются. Он приходит к выводу, что ключевое различие между диффузией и трансмиссией обусловлено высокой способностью детей к восприятию и усвоению языка (трансмиссия) и невысокой способностью у взрослых к изучению языков (диффузия). У. Лабов пишет, что лингвистические характеристики языка могут устойчиво сохраняться и передаваться только через младшее поколение говорящих (Labov, 2007). Межпоколенная передача языка (intergenerational language transmission) является важным показателем в определении степени витальности языка. Уровни витальности различаются от «безопасного уровня», при котором язык используется всеми поколениями, до «критически опасного», при котором старшее поколение лишь «помнит» язык, но не использует его в повседневной коммуникации, и «исчезнувшего», то есть этот язык не имеет говорящих, считающих его родным.

Билингвизм, то есть употребление в речи двух и более языков (впрочем, последнее чаще обозначается как мультилингвизм), подразделяется социолингвистами на индивидуальный и социетальный билингвизм. Последний термин появился сравнительно недавно, он обозначает явление, при котором члены языкового коллектива говорят, помимо своего родного языка, на нескольких других языках, но при этом уровень владения ими невысок (A Dictionary of Sociolinguistics, 2012, с. 27).

В работе А. Портеса и Л. Хао изучались различные способы речевой адаптации и проблема выбора языкового кода у билингвов во втором поколении (Portes, Нао, 1998). При очевидном доминировании английского, у второго поколения билингвов из Латинской Америки тем не менее сохраняется высокая компетенция в родном языке, при этом билингвы второго поколения из Азиатских стран отказываются от использования языка своих родителей даже на бытовом уровне. А. Портес и Л. Хао считают, что подобное различие в адаптации вызвано тем, что испанский язык имеет много общего с английским языком в лингвистических корнях и грамматической структуре, а азиатские языки, в особенности имеющие иероглифическую письменность, труднее изучать и, следовательно, сохранять. Немаловажно и то, что испанский язык поддерживается правительством США в большей степени, чем другие языки (использование в СМИ, в местных газетах и на телевизионных каналах).

Мультилингвизм с недавнего времени стал активнее исследоваться в социолингвистике. Р. Баретт исследует влияние языковой идеологии на языковую коммуникацию, используя метод включенного наблюдения в билингвальной среде (английский и испанский языки) (Barrett, 2006). Под языковой идеологией здесь понимается набор представлений о языке, объясняющий или интерпретирующий значимый поток знаков, который используется говорящими. В результате исследования обнаружилось, что испанский язык выступает средством выражения групповой солидарности испаноязычных сотрудников. Необходимость выражения этой групповой идентичности возникла в связи с использованием англоязычными сотрудниками английского языка с вкраплениями исковерканного испанского, в результате у испаноговорящих сотрудников с узкой англоязычной компетенцией возникало недопонимание при получении инструкций от англоговорящих менеджеров. Р. Баретт приходит к выводу, что языковая идеология одновременно и отражает, и провоцирует расовое и социальное неравенство (Barrett, 2006).

Континуум билингвизма дифференцируется социолингвистами с использованием термина градиент (cline), который обозначает ситуацию, где языковое явление, то есть билингвизм, имеет диапазон или континуум возможностей, называемый градиентом двуязычия или градуированным континуумом двуязычия (A Dictionary of Sociolinguistics, 2012, с. 39). Если изобразить градиент билингвизма в виде шкалы признаков, то с одной стороны шкалы находятся говорящие, у которых компетенция в обоих языках невысокая, они владеют вторым языком в минимальной степени. А на другом конце шкалы находятся люди, в одинаковой степени владеющие двумя языками (это явление называется сбалансированный билингвизм). Большинство билингвов можно расположить посередине между этими двумя крайностями.

В мультилингвизме сравнительно недавно появился термин варилингвизм (varilingualism). «Варилингвизм» обозначает систематическое переключение и смешение кодов в речи говорящих. Этот тип кодового переключения свойственен говорящим в креольском континууме, они используют варилингвизм с самого детства, потребность в котором обусловлена стилистическими и социальными факторами (Yousse, 2009).

\section{Заключение}

Объем актуальных исследовательских тем в современной социальной лингвистике, разумеется, невозможно рассмотреть в рамках одной статьи. Тем не менее была сделана попытка провести обзор некоторых активно развивающихся направлений социолингвистических исследований с целью выявления новых терминологических 
единиц. Было рассмотрено ускорение темпов звуковых изменений в социальных диалектах; влияние социальных характеристик на сближение гласных звуков; диахронические языковые изменения, происходящие в речевых коллективах по мере взросления говорящего; диффузия и трансмиссия в межпоколенной передаче языка и их связи с уровнем языковой витальности; речевая адаптация и особенности выбора языкового кода в разных социальных ситуациях; связь языковой идеологии и социального неравенства.

В результате мы приходим к следующим выводам. Термины, выявленные в процессе исследования, еще не получили широкого распространения в русскоязычной социальной лингвистике, но они, вероятно, со временем обретут системность и займут устойчивое место в ее понятийном аппарате. Новые термины постоянно продолжают появляться, и дальнейшей задачей социолингвистов, возможно, является унифицирование метаязыка науки.

Перспективы дальнейшего исследования видятся в том, что необходимо продолжать работу над дальнейшим совершенствованием терминосистемы социолингвистики. Эффективная и современная система понятий будет способствовать продвижению социолингвистической научной мысли.

\section{Финансирование | Funding}

RU Исследование выполнено при финансовой поддержке РФФИ и Немецкого научно-исследовательского сообщества в рамках научного проекта № 21-512-12002 ННИО_а «Методы прогнозирования и будущие сценарии развития языковой политики (на примере многоязычной Российской Федерации)».

EN The reported study was funded by RFBR and DFG, project number № 21-512-12002

\section{Источники | References}

1. Словарь социолингвистических терминов. М.: Институт языкознания РАН, 2006.

2. A Dictionary of Sociolinguistics / ed. by J. Swann, etc. Edinburgh: Edinburgh University Press, 2012.

3. Barrett R. Language ideology and racial inequality: competing functions of Spanish in an Anglo-owned Mexican restaurant. 2006. URL: https://uknowledge.uky.edu/lin_facpub/10/

4. Currie H. C. A projection of socio-linguistics: the relationship of speech and its social status // The Southern Speech Journal. 1952. № 18.

5. Docherty G. J., Foulkes P. Sociophonetic Variation in 'Glottals' in Newcastle English. 2005. URL: https://pdfs. semanticscholar.org/57e4/7c2bf9fe5c90073469f674b7d75769771c99.pdf

6. Hazen K. An Introductory Investigation into Bidialectalism. 2001. URL: https://core.ac.uk/download/pdf/76381689.pdf

7. Labov W. Transmission and diffusion. 2007. URL: https://www.ling.upenn.edu/ wlabov/Papers/TD.pdf

8. Labov W., Ash S., Boberg C. Atlas of North American English. The Hague: Mouton de Gruyter, 2006.

9. Oschwald J., Schättin A., Bastian C. A. von, Souza A. S. Bidialectalism and Bilingualism: Exploring the Role of Language Similarity as a Link between Linguistic Ability and Executive Control. 2018. URL: https://www.frontiersin.org/ articles/10.3389/fpsyg.2018.01997/full

10. Portes A., Hao L. Bilingualism and Loss in the Second Generation. 1998. URL: https://econwpa.ub.uni-muenchen.de/ econ-wp/mac/papers/9805/9805006.pdf

11. Trudgill P. A Glossary of Sociolinguistics. Oxford: Oxford University Press, 2003.

12. Yousse V. Varilingualism: a discrete sub-type of language competence. 2009. https://www.tandfonline.com/doi/abs/ 10.1080/14769670500066248?journalCode=ijmc20

\section{Информация об авторах | Author information}

RU Кириленко Светлана Владимировна ${ }^{1}$, к. филол. н., доц.

${ }^{1}$ Институт языкознания Российской академии наук, г. Москва

EN Kirilenko Svetlana Vladimirovna ${ }^{1}, \mathrm{PhD}$

${ }^{1}$ Institute of Linguistics of RAS, Moscow

${ }^{1}$ svetlanavk@inbox.ru

\section{Информация о статье | About this article}

Дата поступления рукописи (received): 07.09.2021; опубликовано (published): 29.10.2021.

Ключевые слова (keywords): социолингвистическая терминология; диалекты; билингвизм; мультилингвизм; языковые изменения; sociolinguistic terminology; dialects; bilingualism; multilingualism; language changes. 